EDITORIAL

\title{
Nipah Virus Endemic in Bangladesh
}

\author{
Md. Tahminur Rahman \\ Prof. Dr. Md. Tahminur Rahman, Professor \& Head, Pathology \\ Anwer Khan Modern Medical College, Dhanmondi, Dhaka.
}

Nipah is a viral zoonotic disease transmitted by infected fruit juice specially raw palm juice unpastuerised, contaminated fruits eaten by fruit bats and taking it without washing, peeling or cooking ${ }^{1,2}$. Since 1997 Nipah virus infection has emerged repeatedly in South East Asia including Bangladesh. The first case of Nipah virus infection was reported in Malaysia in 1998-99 and retrospective diagnosis showed the infection was present from $1997^{3}$. First infection in India was reported in January-February 2001 in Shiliguri district neighbouring Bangladesh where 66 cases were reported with a $74 \%$ mortality. $75 \%$ patients were hospital staff or had visited one of the other patients in hospital indicating person to person contact ${ }^{4}$.

In Bangladesh, Nipah was first reported from Meherpur district in April-May 2001 with 13 cases and 9 fatalities $(69 \%$ mortality). Susequently this was followed in chronological order in January 2003 in Naogaon district with 12 cases with 8 fatalities(67\% mortality), January-February 2004 in Manikganj and Rajbari districts 42 cases with 14 fatalitiess (33\% mortality), February -April 2004 in Faridpur district 36 cases with 27 fatalities (75\% mortality), January 2005 in Tangail district 12 cases with 11 fatalities( $92 \%$ mortality), January and February 2005 an outbreak in Thakurgaon affecting 7 people and 3 deaths (42\% mortalities) February -May 2007 in Kustia district with 8 cases and 5 fatalities (55\% mortality), February-March 2008 in Manikganj and Rajbari districts with 9 cases and 8 fatalities (88\% mortalities). February-May 2007 in Nadia district in India 50 suspected cases were reported with 3-5 fatalities (10-17\% mortalities). These were due to person to person contact. Lastly in this year in February an outbreak occurred in
Hatibandha, Lalmonirhat, Dinajpur with 46 cases and 26 fatalities (56.5\% mortality) with 21 children dying in one day on $4^{\text {th }}$ February 2011 alone. Most of these districts are bordering with India ${ }^{6,7,9}$.

Fruits bat of the family Pteropodidae specially Pteropus genus are natural hosts for Nipah virus. There is no apparent disease in fruit bats because of natural immunity. It is now assumed that Henipa viruses overlaps with Pteropus category. This hypothesis was reinforced with evidence of Henipavirus in different geographic locations like Australia, Bangladesh, Cambodia, China, India, Indonesia, Madagasker, Malayasia, papua new Guinea, Thiland and Timor Leste. Recently African fruit bats of genus Eidolon, family Pteropodidae was found positive for antibodies against Nipah and hendra viruses. Nipah outbreaks in pigs and other domestic animals like horses, goats sheep, cats and dogs were also reported.

Infection spreads by direct contact with infected pigs and their contaminated tisuues. Fruit bat urine, saliva are the main route of transmission in humans when they eat raw unpasteurised juice and beaten, contaminated fruits unwashed, uncooked and unpeeled. Nipah virus infection ranges from asymptomatic to fatal encephalitis. Symptoms include Influenza-flu like nausea, vomiting, headache, myalgia, high fever and sore throat, Neurological symptoms like dizziness, drowsiness, altered consciousness, convulsions, coma indicate acute encephalitis. Some people can experience atypical pneumonia and severe respiratory problems including ARDS. Encephalitis and seizure occurs in severe cases progressing to coma within 24-48 hours ${ }^{10}$. The incubation period varies from 4 hours to 45 days. The fatality rate estimated is $40-$ 
$75 \%$. Most people who survive encephalitis make a full recovery, $20 \%$ left with residual neurological complications like persistent convulsions and personality changes. After recovery a small number may develop delayed onset of encephalitis. Long term persistent neurologiocal symptoms are observed in $15 \%$ of patients.

Diagnosis is usually done by Virus isolation, the detection of antigens or nucleic acids by serology, histopathology from affected organ. Nipah virus can be recovered in many cell lines including Vero(Africal green monkey Kidney), RK-13, BHK or porcine spleen. Virus can also be identified in cultures by immunostaining or virus neutralization. Electron microscopy and immune electron microscopy can aid in identification. Nipah virus has been isolated from blood,throat swab, CSF and urine samples of affected person. Viral antigens can be detected in formalin fixed tissues by IHC Antigens found in CNS, Lung and Kidney tissues. RTPCR techniques can be used to detect antibodies to Nipah virus in serum and CSF. Acute and convalescent samples should be collected and serologic tests should be done by ELISA and serum neutralization ${ }^{11}$.

There are currently no drugs or vaccines available to treat Nipah virus infection. So there is no specific treatment available for Nipah virus infection. Most treatment are supportive and may include mechanical ventilation, treatment of symptoms. Ribavirin is promising in some outbreaks but remains to be fully investigated. So the most important aspect is isolation of the infected person and to send him to local hospital for diagnosis, treatment and preventive measures. As there is no specific treatment available, the following measures should be taken in a Nipah virus affected region. These are divided into two aspects of prevention. One is among the animals ie, Pigs, bats, dogs, cats, horses and the second group is for humans. Animals with Nipah virus infections should be killed, slaughtered, properly incinerated to prevent spreading as human infections. Fruit tree plantations should be stopped in areas where pigs are kept, Bat cannot contaminate raw palm juices and bite fruits. Dogs and cats should be prevented from contacting infected pigs roaming between farms. In endemic areas pigs and fruit bats should be avoided. Good personal hygiene should be maintained by hand washing with antiseptic lotion, Unpasteurised or raw fruit juice should not be drunk Fruits should be washed thoroughly, peeled or cooked before consumption. People who come in close contact with potentially infected animals should wear protective clothing, impermeable gloves, masks, goggles and boots. Once infected and shows flu like symptoms with high fever, headache, myalgia, nausea, vomiting, the affected person should be immediately transferred to local hospital or medical personal for treatment. If patient develop encephalitis symptoms like drowsiness, disorientation, convulsions, coma, respiratory distress like ARDS, the patient should be transferred to intensive supportive care for urgent treatment. Quarantine measures like closing of schools, avoidance of crowding in home, places should be imposed in the affected area. Most importantly media, local people's representative, health officials, government should take part actively in creating awareness, not to get panic and to explain what preventive measures to take in the affected area.

\section{References}

1. Chua KB, Bellini WJ, Rota PA, Harcourt BH, Tamin A, Lam SK, et al. Nipah virus: a recently emergent deadly paramyxovirus. Science. 2000; 288: 1432-5.

2. Chua KB, Bellini WJ, Rota PA, Harcourt BH, Tamin A, Lam SK, Ksiazek TG, Rollin PE, Zaki SR, ShiehW, Goldsmith CS, Gubl Hsu VP, Hossain MJ, Paeashar UD, Ali MM, Ksiazek TG, Kuzmin I, et al. Nipah virus encephalitis reemergence. Bangladesh. Emerg Infect Dis. 2004; 12: 2082-7.

3. Hsu VP, Hossain MJ, Paeshar UD, Ali MM, Ksiazek TG, Kuzmin I, et al. Nipah virus encephalitis emergence. Bang Emerg Infec Dis. 2004; 12: 2082-7

4. Chadha MS, Comer JA, Lowe L, Rota PA, Rollin P, Bellini WJ, et al. Nipah virus-associated encephalitis outbreak, Siliguri, India. Emerg Infect Dis. 2006; 12:235-40. 
5. World Health Organization (September 2001), Fact sheet $\mathrm{N}^{\circ} 262$ : Nipah virus

6. http://en.wikipedia.org/wiki/Henipavirus, accessed in February 17, 2011.

7. http://www.thedailystar.net/newDesign/latest_news.php? nid=28413, accessed in Feb 11, 2011.

8. ICDDRB Nipah encephalitis outbreak over wide area of western Bangladesh, 2004. Health Sci Bull 2004a; 2: 7- 11

9. ICDDRB Person-to-person transmission of Nipah virus during outbreak in Faridpur District. Health Sci Bull. 2004b; 2: 5-9.
10. Parashar UD, Sunn LM, Ong F, Mounts AW, Arif MT, Ksiazek TG, Kamaluddin MA, Mustafa AN, Kaur H, Ding LM, Othman G, Radzi HM, Kitsutani PT, Stockton PC, Arokiasamy J, Gary HE, Anderson LJ Case control study of risk factors for human infection with a new zoonotic paramyxovirus, Nipah virus, during a 19981999 outbreak of severe encephalitis in Malaysia. J Infect Dis. 2000; 181: 1755-1759.

11. Chua KB, Lam SK, Goh KJ, Hooi PS, Ksiazek TG, Kamarulzaman A, Olson J, Tan CT The presence of Nipah virus in respiratory secretions and urine of patients during an outbreak of Nipah virus encephalitis in Malaysia. J Infect 2001; 42: 40-43. 